\title{
ACTIVITY OF HYDROLYSIS ENZYMES IN DIFFERENT INSTAR LARVAE OF THE AMERICAN BOLLWORM, HELICOVERPA ARMIGERA (HUBNER)
}

\author{
Abdel-Wahed, M. S. ${ }^{(1)}$; Mahmoud, K. W. ${ }^{(1)}$; Khidr, A. A. ${ }^{(2)}$ \\ and Alashry, Hend, A. ${ }^{(2)}$ \\ 1) Plant Protection Department, Pesticides Department, Faculty of Agric., Ain \\ Shams University 2) Plant Protection Research Institute, Agricultural \\ Research Center, Dokki-Giza, Cairo.
}

\begin{abstract}
Enzymes activity included acetylcholinesterase, non-specific $\alpha$ and $\beta$ esterases and alkaline phosphatase were determined calorimetrically in the whole homogenates of the different instar larvae; $3^{\text {rd }}, 4^{\text {th }}, 5^{\text {th }}$ and $6^{\text {th }}$ of the field strain as well as the baseline, laboratory strain of American bollworm, Helicoverpa armigera. The results indicated that the enzymes activity levels in the different instar larvae of the field strain were markedly higher than that in the laboratory strain at the respective instar larvae. The enzymatic activity levels increased steady from the $3^{\text {rd }}$ to the $6^{\text {th }}$ instar larvae. A sharp increase in the enzymatic activity levels were determined in the $6^{\text {th }}$ instar larvae. The average levels of the enzymatic activity in both field colony and laboratory strain were 11.630 and $3.627 \mu \mathrm{g}$ acetyl bromide released / min. /individual for A.Ch.E.; 8.819 and $3.430 \mu \mathrm{g} \alpha$-naphthol released/ $\mathrm{min} / \mathrm{individual}$ and the corresponding values were ranged between 5.232 and $3.218 \mu \mathrm{g} \beta$ - naphthol released / $\mathrm{min} /$ larva for beta esterase; respectively and157.669 and 50.428 unit X $10^{3} /$ larva for alkaline phosphatase; respectively
\end{abstract}

Key words: Helicoverpa armigera, field and laboratory strain, enzymes activity. 
J. Environ. Sci.

Institute of Environmental Studies and Research - Ain Shams University

\section{INTRODUCTION}

The cotton bollworm, Helicoverpa armigera, is one of the major agricultural pest species in the Old World and recently also of the New World. This noctuid moth species is highly polyphagous and possesses a huge geographical distribution and the ability to quickly evolve resistance to insecticides from different chemical classes. (JouBen and Heckel, 2016). Larva of $H$. armigera may consume as many 8 squares, 1 flower and 1, 2/3 bolls during its life. Thus relative few larvae per acre may inflict significant yield losses to cotton while large number may cause severe damage. The extensive use of chemical insecticides for the control of the cotton bollworms in Egypt has created several problems, such as development of resistance, pesticides hazards and the disturbance of normal balance between some insect pests and their natural enemies.

It is known that the population of $H$. armigera can develop various degrees of resistance to many insecticides (Hammad, 1977). However, no information is available concerning the biochemical mechanisms by which this pest can develop resistance to insecticides.

Hydrolases are known to play an important role in the detoxification mechanisms of insecticides (Khidr, 1982).

In this study, hydrolases included acetylcholinesteras, $\alpha$ and $\beta$ - esterases and alkaline phosphatase activities in different instar larvae of both field strain and laboratory strain of $H$. armigera were determined 


\section{MATERIALS AND METHODS}

\section{Rearing technique:}

A field strain and a laboratory strain of the american bollworm, Helicoverpa armigera were used in this study. The field colony was collected from the Quesna district, Menoufia governorate, reared in the laboratory for one generation and then it was subjected to the analysis. The laboratory strain was reared in the laboratory away from any insecticide for more than 8 generations under constant conditions of $27 \pm 1^{\circ} \mathrm{Cand} 70 \pm 5 \%$ R.H. Instar larvae were fed on lettuce leaves. The newly hatched larvae were reared in groups in glass containers covered with muslin tied or fixed with rubber bands until the third instars. To avoid cannibalism, from the fourth, to sixth instars were confined individually in convenient glass tubes $(2.5 \times 7.5 \mathrm{~cm})$ covered with a plug of cotton until pupation. The resulting pupae were transferred to convenient glass tubes covered with a plug of cotton. After emergence, four pairs of newly emerged moths were placed in chimney glass cages $(150 \mathrm{ml}$ volume, $15 \mathrm{~cm}$ height, $9.5 \mathrm{~cm}$ upper diameter and $12.5 \mathrm{~cm}$ lower diameter) for mating. The cages were provided with honey bee solution $10 \%$ for adult's feeding and strips of muslin as a suitable site for oviposition.

\section{Preparation of the insect homogenates:}

Batches of four instar larvae were collected, weighed and counted. Two days old of the third (24-28 mg/larva), $4^{\text {th }}(35-40 \mathrm{mg} / \mathrm{larva}), 5^{\text {th }}(73-82$ $\mathrm{mg} / \mathrm{larva})$ instars and three days old for the $6^{\text {th }}$ instar (310-320 mg/larva) were used. Appropriate quantities of the instar larvae were used in three replicates to obtain suitable homogenates as follows: 15 larvae for both of $3^{\text {rd }}$ and $4^{\text {th }}$ instars; and 10 larvae for both $5^{\text {th }}$ and $6^{\text {th }}$ instars were used for each replicate. 
Each batch was mechanically homogenized I 10 volumes $(w / v)$ of $0.1 \mathrm{M}$ phosphate buffer, $\mathrm{Ph} 7$ for 2 minutes using a Teflon homogenizer surrounded with a jacket of crushed ice. The homogenates were then centrifuged at 4000 r.p.m.in convenient glass tubes covered with a plug of cotton r.p.m. for 30 minutes at $4{ }^{\circ} \mathrm{C}$ using cooling centrifuge. The resultant supernatant ( as a source of the measured biochemical aspects) was used to determine the activities of four hydrolytic enzymes, i.e. acetylcholinesterase ( A. Ch.E.) , $\alpha$ and $\beta$ - esterases and alkaline and acid phosphatases.

\section{Hydrolases activity:}

\subsection{Determination of Acetylcholinesterase (A.Ch.E.) activity:} Acetylcholinesterase activity $(0.4 \mathrm{ml}$ of enzyme soluation was measured colorimetrically according to the method described by Ellman et al. (1961), which is based on the hydrolysis of Acetylcholine (ASCH) as a substrate. Thiocholine reacts with 5,5-dithio-bis-(2-nitrobenzoic acid) (DTNB as a color developer) to produce 5-thio-2-nitrobenzoic acid giving a yellow color, which can be determined, spectrophotometrically at a wave length of $214 \mathrm{~nm}$. A.Ch.E. activity was measured and expressed as $\mu \mathrm{g}$ substrate hydrolyzed /individual/min.

3.2. Determination of alkaline phosphatase activity: The activities of alkaline phosphatase (at $\mathrm{pH} 4.9$ ) were determined according to the method described by Powell and Smith, (1954). The reaction mixture consisting of 1 $\mathrm{ml}$ carbonate buffer, $1 \mathrm{ml}$ of $0.01 \mathrm{M}$ disodium phenyl phosphate (substrate) and $0.1 \mathrm{ml}$ of tissue supernatant. was incubated for 30 minutes at $37^{\circ} \mathrm{C}$. The reaction was stopped by addition of $0.8 \mathrm{ml}$ of $0.5 \mathrm{~N} \mathrm{NaOH}$ then $1.2 \mathrm{ml}$ of 
$0.5 \mathrm{~N} \mathrm{NaHCO}_{3}, 1 \mathrm{ml}$ of 4-aminoantipyrine solution and $1 \mathrm{ml}$ of potassium ferricyaimde were added to produced a red or purple color. The amount of phenol liberated in the media corresponds to the enzyme activity hydrolyzing the substrate, i.e., the more activity of the enzyme on the substrate, the more liberation of phenol. The produced color was measured colorimetrically at $510 \mathrm{~nm}$. The enzymatic activity is expressed as unitx $10^{3} /$ larva.

3.3. Determination of non-specific esterases activity: Alpha esterases ( $\alpha$ esterases) and beta esterases ( $\beta$ esterases) were determined according to (Van Asperen, 1962) using alpha naphthyl acetate or beta naphthyl acetate as substrates, respectively.

The reaction mixture consisted of $5 \mathrm{ml}$ substrate solution (3x10-4 M $\alpha$ - or $\beta$-naphthylacetate, $1 \%$ acetone and $0.1 \mathrm{M}$ phosphate buffer, $\mathrm{pH} 7$ ) and $20 \mu \mathrm{l}$ of larval homogenate. The mixture was incubated for exactly $15 \mathrm{~min}$ at $27{ }^{\circ} \mathrm{C}$, then $1 \mathrm{ml}$ of diazoblue color reagent ( prepared by mixing 2 parts of $1 \%$ diazoblue $\mathrm{B}$ and 5 parts of $5 \%$ sodium laurel sulphate) was added. The developed color was read at $600 \mathrm{~nm}$ for $\alpha$-and $\beta$-naphthol produced for the substrate, respectively. The enzymatic activity was measured and expressed as mg/naphthol released/larvae/min.

\section{RESULTS AND DISCUSSION}

1. Hydrolases activity in different instar larvae of field strain and laboratory strain of the American bollworm, Helicoverpa armigera (Hubner):

The activity of the tested hydrolyzing enzymes i.e., acetylcholinesterase, $\alpha$ - and $\beta$-esterases, alkaline and acid phosphatases as well as were estimated during various stages of both a field strain collected from Quesna district, 
Menoufia Governorate and a laboratory strain of $H$. armigera. Determination of enzymes activity in laboratory strain and in field strain might throw light on inductive effect of insecticides on the insect.

1.1. Acetylcholinesterase (A. Ch. E.) actvity: Organophosphorus and carbamate insecticides are known to be affected acetylcholinesterase. Therefore, the affected "i.e. phosphorylated-or-carbamated" enzyme is inhibited and therefore, incapable of carrying out its normal function. Accordingly, it seemed worthy to determine the insect A. Ch. E. activity at different instar larvae of $H$. armigera.

The biochemical assays of A. Ch. E. activity in various instar larvae of field strain and the laboratory strain of $H$. armigera are represented in Table 1. The obtained data showed marked differences between field strain and laboratory strain at respective instars of the insect. Moreover, marked differences were recorded for A. Ch. E. between different instars of the insect within the field strain as well as within the laboratory strain. Comparison between the enzymatic activity per individual for the insect instars, was the highest at $6^{\text {th }}$ instar larvae where the corresponding enzymatic activity levels were $36.486 \mu \mathrm{g}$ acetyl bromide / $\mathrm{min} /$ individual and $117.968 \mu \mathrm{g}$ acetyl bromide released / $\mathrm{min}$. /gram tissue, followed by the $5^{\text {th }}$ instar larvae, where the corresponding enzymatic activity levels were $6.896 \mu \mathrm{g}$ acetyl bromide released / min. /individual and $94.466 \mu \mathrm{g}$ /acetyl bromide released /gram tissue ; respectively. The lowest enzymatic activity levels were recorded in the $3^{\text {rd }}$ instar larvae, The corresponding enzymatic activity levels exhibited $0.633 \mu \mathrm{g}$ acetyl bromide released / min. /individual and $26.375 \mu \mathrm{g}$ acetyl 
bromide released / min / gram tissue. Meanwhile the activity of A. CH. E. for the $4^{\text {th }}$ instar larvae was $2.506 \mu \mathrm{g}$ acetyl bromide released / min. /individual and $71.600 \mu \mathrm{g}$ acetyl bromide released / min. / gram tissue. This finding in field strain was similar to those in the laboratory strain. In this respect, the activities of acetyl cholinesterase for the $3^{\text {rd }}, 4^{\text {th }}, 5^{\text {th }}$ and $6^{\text {th }}$ instar larvae of $H$. armigera laboratory strain per individuals and gram tissue were $0.342,0.854$, 2.173 and 11.137 substrate hydrolyzed / min. / individual; respectively, and $12.214,24.400,29.767$ and $35.926 \mu \mathrm{g}$ substrate hydrolyzed/min./gram tissue; respectively.

The A. Ch. E. activity ratio values (i.e., field strain :laboratory strain) were ranged between 1.851 and 3.284. This finding showed clearly the inductive effect of toxic chemicals in the insect environment, including organophosphates and carbamate insecticides on the enzyme activity in insect body.

Table (1): Acetyl cholinesterase activity in the whole homogenates of different instar larvae of field and laboratory strain of the American bollworm, Helicoverba armigera

\begin{tabular}{|c|c|c|c|c|c|c|}
\hline \multirow[b]{2}{*}{$\begin{array}{l}\text { Instar } \\
\text { larvae }\end{array}$} & \multicolumn{2}{|c|}{ Field strain $(\mathbf{F})$} & \multicolumn{2}{|c|}{ Laboratory strain (L) } & \multicolumn{2}{|c|}{ Activity ratio F/L } \\
\hline & $\begin{array}{c}\text { Activity } \\
\text { individual } \\
\mathbf{x 1 0 ^ { - 1 * }}\end{array}$ & $\begin{array}{l}\text { Activity } \\
\text { gram } \\
\text { tissue }\end{array}$ & $\begin{array}{c}\text { Activity } \\
\text { individual } \\
\times 10^{-1}\end{array}$ & $\begin{array}{c}\text { Activity } \\
\text { gram } \\
\text { tissue }\end{array}$ & $\begin{array}{c}\text { F/L per } \\
\text { individual }\end{array}$ & $\begin{array}{c}\text { F/L per } \\
\text { gram } \\
\text { tissue }\end{array}$ \\
\hline $3^{\text {rd }}$ & $0.633^{\mathrm{d}}$ & $26.375^{\mathrm{d}}$ & $0.342^{\mathrm{d}}$ & $12.214^{\mathrm{d}}$ & 1.851 & 2.159 \\
\hline $4^{\text {th }}$ & $2.506^{\mathrm{c}}$ & $71.600^{c}$ & $0.854^{\mathrm{c}}$ & $24.400^{\mathrm{c}}$ & 2.934 & 2.934 \\
\hline $5^{\text {th }}$ & $6.896^{\mathrm{b}}$ & $94.466^{\mathrm{b}}$ & $2.173^{b}$ & $29.767^{\mathrm{b}}$ & 3.173 & 3.184 \\
\hline $6^{\text {th }}$ & $36.486^{\mathrm{a}}$ & $117.968^{\mathrm{a}}$ & $11.137^{\mathrm{a}}$ & $35.926^{\mathrm{a}}$ & 3.276 & 3.284 \\
\hline mean & $11.630^{\mathrm{a}}$ & $77.602^{\mathrm{a}}$ & $3.627^{\mathrm{b}}$ & $25.577^{\mathrm{b}}$ & 2.809 & 2.890 \\
\hline L.S.D & 1.790 & 6.875 & 1.409 & 3.394 & & \\
\hline
\end{tabular}

*/Activity is expressed as $\mathrm{Mg} \mathrm{AchBr/} \mathrm{min} \mathrm{/} \mathrm{individual}$

**/ Activity is expressed as $\mathrm{Mg} \mathrm{AchBr/min} \mathrm{/gram} \mathrm{tissue}$ 


\section{Alpha and beta nonspecific esterase's activity:}

Non-specific esterases or esterases hydrolyzing $\alpha$ and $\beta$-naphthyl acetate were classified as Cholinesterase, carboxyl esterase and aryl esterase according to their reaction with organophosphates and serine (Meyers, 1959; and Dixon and Webb, 1964). These types of enzymes play a vital role in the mechanism of resistance (Sudderuddin, 1973; Ahmed and Forgash, 1976 and Khidr, 1982).

Comparison of non-specific esterase activity in the whole homogenates of various instars of the American bollworm, H. armigera revealed that some physiological differences were existed between the field strain and the laboratory strain (Tables 2 and 3). It is clear that the levels of $\alpha$ and $\beta$ esterase's activity were much higher in all field instar larvae with that of the respective laboratory strain. It is obvious that the levels of $\alpha$-esterase's activity in the larval instars were much higher than that of the respective $\beta$ esterase's activity. The levels of $\alpha$-esterases activity in the different instar larvae of the field strain were ranged between 1.233 and 25.307 with mean of $8.819 \mu \mathrm{g} \alpha$-naphthol released/ $\mathrm{min} /$ individual, and the corresponding values were ranged between 44.025 and 81.635 with mean of $62.152 \mu \mathrm{g} \alpha$-naphthol released/ min/g. b. wt.; whereas the enzymatic activity levels in the different instar larvae of the baseline, laboratory strain were ranged between 0.307 and 10.887 with a mean of $3.430 \alpha^{-}$naphthol released/ min/ larva, and the corresponding values were ranged between 10.958 and 35.119 with mean of $22.390 \mu \mathrm{g} \alpha$-naphthol released/ min./g. b. wt. 
Table (2): Alpha esterases activity in the whole homogenates of different instar larvae of field and laboratory strain of the American bollworm, Helicoverpa armigera

\begin{tabular}{|c|c|c|c|c|c|c|}
\hline \multirow[b]{2}{*}{$\begin{array}{l}\text { Larval } \\
\text { instars }\end{array}$} & \multicolumn{2}{|c|}{ Field strain (F) } & \multicolumn{2}{|c|}{ Laboratory strain $(\mathrm{L})$} & \multicolumn{2}{|c|}{ Activity ratio } \\
\hline & $\begin{array}{c}\text { Activity } \\
\text { individual } \\
\mathbf{x 1 0}^{-1^{*}}\end{array}$ & $\begin{array}{l}\text { Activity } \\
\text { gram } \\
\text { tissue }\end{array}$ & $\begin{array}{c}\text { Activity } \\
\text { individual } \\
\mathbf{x 1 0}^{-1^{*}}\end{array}$ & $\begin{array}{l}\text { Activity } \\
\text { gram } \\
\text { tissue** }\end{array}$ & $\begin{array}{c}\text { F/L per } \\
\text { individua } \\
l\end{array}$ & $\begin{array}{c}\text { F/L } \\
\text { per } \\
\text { gram } \\
\text { tissue }\end{array}$ \\
\hline $3^{\text {rd }}$ & $1.233^{\mathrm{c}}$ & $44.025^{\mathrm{c}}$ & $0.307^{\mathrm{c}}$ & $10.948^{\mathrm{d}}$ & 4.016 & 4.018 \\
\hline $4^{\text {th }}$ & $2.367^{\mathrm{bc}}$ & $59.133^{b}$ & $0.788^{\mathrm{c}}$ & $19.700^{c}$ & 3.001 & 3.091 \\
\hline $5^{\text {th }}$ & $5.169^{b}$ & $63.815^{b}$ & $1.736^{\mathrm{b}}$ & $23.781^{b}$ & 2.978 & 2.683 \\
\hline $6^{\text {th }}$ & $25.307^{\mathrm{a}}$ & $81.635^{\mathrm{a}}$ & $10.887^{\mathrm{a}}$ & $35.119^{\mathrm{a}}$ & 2.325 & 2.325 \\
\hline mean & $8.819^{\mathrm{a}}$ & $62.152^{\mathrm{a}}$ & $3.430^{\mathrm{b}}$ & $22.390^{\mathrm{b}}$ & 3.080 & 3.029 \\
\hline L.S.D & 3.122 & 4.800 & 0.941 & 2.947 & $=$ & \\
\hline
\end{tabular}

*/Activity is expressed as Mg OC.naphthol / min / individual .

**/ Activity is expressed as Mg OC.naphthol/min /gram tissue.

Table (3): Beta- esterases activity in the whole homogenates of different instar larvae of field and laboratory strain of the American bollworm, Helicoverpa armigera

\begin{tabular}{|c|c|c|c|c|c|c|}
\hline \multirow[b]{2}{*}{$\begin{array}{l}\text { Larval } \\
\text { instars }\end{array}$} & \multicolumn{2}{|c|}{ Field strain (F) } & \multicolumn{2}{|c|}{ Laboratory strain (L) } & \multicolumn{2}{|c|}{ Activity ratio F/L } \\
\hline & $\begin{array}{c}\text { Activity } \\
\text { individual* }\end{array}$ & $\begin{array}{l}\text { Activity } \\
\text { gram } \\
\text { tissue }^{* *}\end{array}$ & $\begin{array}{c}\text { Activity } \\
\text { individual }\end{array}$ & $\begin{array}{c}\text { Activity } \\
\text { gram } \\
\text { tissue }\end{array}$ & $\begin{array}{c}\text { F/L per } \\
\text { individual }\end{array}$ & $\begin{array}{c}\text { F/L } \\
\text { per } \\
\text { gram } \\
\text { tissue }\end{array}$ \\
\hline $3^{\text {rd }}$ & $0.668^{\mathrm{c}}$ & $23.857^{\mathrm{d}}$ & $0.291^{\mathrm{b}}$ & $10.392^{b}$ & 2.295 & 2.296 \\
\hline $4^{\text {th }}$ & $1.246^{\mathrm{bc}}$ & $31.150^{\mathrm{c}}$ & $0.484^{\mathrm{b}}$ & $12.100^{\mathrm{b}}$ & 2.574 & 2.573 \\
\hline $5^{\text {th }}$ & $2.876^{\mathrm{b}}$ & $39.384^{b}$ & $2.177^{\mathrm{b}}$ & $29.822^{\mathrm{a}}$ & 1.321 & 1.321 \\
\hline $6^{\text {th }}$ & $16.135^{\mathrm{a}}$ & $52.048^{\mathrm{a}}$ & $9.919^{\mathrm{a}}$ & $31.997^{\mathrm{a}}$ & 1.627 & 1.627 \\
\hline mean & $5.232^{\mathrm{a}}$ & $36.610^{\mathrm{a}}$ & $3.218^{\mathrm{b}}$ & $22.726^{b}$ & 1.954 & 1.954 \\
\hline L.S.D & 2.105 & 3.764 & 2.103 & 2.977 & - & - \\
\hline
\end{tabular}

*/Activity is expressed as $\mathrm{Mg}$ 2-naphthol / min / individual .

**/ Activity is expressed as Mg 2-naphthol /min / g.b.wt. 
As presented in Table 3, $\beta$ - esterases activity levels in the different instar larvae of the field colony were ranged between 0.668 and 16.135 with mean of $5.232 \mu \mathrm{g} \beta$ - naphthol released / min/lava.; whereas the enzymatic activity levels in the different larval instars of the laboratory strain were ranged between 0.291 and 9.919 with mean of $3.218 \mu \mathrm{g} \beta$ - naphthol released / min/ larva.

Alkaline phosphatase activity: The obtained results of alkaline phosphateses activity in the larval homogenates of $H$. armigera are summarized in Table (4). It is evident that the enzymatic activity increased steadily from the $3^{\text {rd }}$ instar larvae to the $6^{\text {th }}$ instar. This was the general trend of results either for field strain or laboratory strain insect instars. The enzymatic activity in the field strain instar larvae was much higher than that of those in the corresponding in the laboratory strain. The enzyme activity levels in the instar larvae $\left(3^{\text {rd }}, 4^{\text {th }}, 5^{\text {th }}\right.$ and $\left.6^{\text {th }}\right)$ homogenates of the field colony were ranged between 26.749 and 459.861 with mean of 157.669 units $X 10^{3} /$ larva and it was ranged between 955.333 and 1483.423 with an average of 1191.102 unit $\mathrm{X} 10^{3} /$ gram body weight. On the other hand, alkaline phosphatase activities in the corresponding larval instars of the base line, laboratory strain were ranged between 8.642 and 145.255 with an average of 50.428 unit X10 3 larva, and these activity levels were ranged between 308.643 and 468.565 with an average of 387.600 unit $\mathrm{X} 10^{3} / \mathrm{gram}$ body weight. Although biochemical monitoring tools such as enzymes activity assays by no means a universal alternative to conventional bioassay technique, they can complement bioassays populations. For example, esterases catalyze hydrolysis of several 
types of esters, and many insecticides such as organophosphates, carbamates, and pyrethroids containing ester groups (Seleman 2014).

In this respect, it is obvious that the different larval instars of the field strain recorded much higher enzymes activity levels than the corresponding of the laboratory strain. In this field of study, Khidr (1982), Siegfried and Zera (1994) and Wilson and Ashok (1998) mentioned that the most common mechanism of resistance in the insect species to the tested insecticides is related to several types of metabolic enzymes. In this respect of investigation associated to resistance mechanism in insect pests to the different insecticidal treatments; Khidr (1982) studied the effect of S, S, S -tributyl phosphorothioate (DEF), an esterase inhibitor and n-propyl paraoxon, a phosphatases inhibitor on the toxicity of some organophosphate insecticides against the $4^{\text {th }}$ instar larvae of $H$. armigera. He revealed that the synergistic ratio was higher for the field strain as compared with that of the laboratory strain. Hassan and Mostafa (2000). studied the effect of DEF an esterases inhibitor on the toxicity of of three organophosphate insecticides against the $3^{\text {rd }}$ instar larvae of the Mediterranean fruit fly, Ceratitis capitata. They indicated that the synergistic ratios were much higher in the field strain than the laboratory strain. Young et al. (2005) reported that pyrethroid resistance in field populations of Australian $H$. armigera is primarily a consequence of the over production of esterases isoenzymes which metabolites and sequester pyrethroids. (Hung and Ottea 2004) reported that esterases activity associated with resistance to organophosphorus insecticides in Heliothis virescens larvae were detected. 
Table (4): Alkaline phosphatase activity in the whole homogenates of instar larvae of the field and laboratory strain of Helicoverpa armigera.

\begin{tabular}{|c|c|c|c|c|c|c|}
\hline \multirow{2}{*}{$\begin{array}{c}\text { Instar } \\
\text { larvae }\end{array}$} & \multicolumn{2}{|c|}{ Field Colony (F) } & \multicolumn{2}{|c|}{ Laboratory strain (L) } & \multicolumn{2}{|c|}{ Activity ratio F/L } \\
\cline { 2 - 7 } & $\begin{array}{c}\text { Activity } \\
\text { individual* }\end{array}$ & $\begin{array}{c}\text { Activity } \\
\text { gram } \\
\text { tissue** }\end{array}$ & $\begin{array}{c}\text { Activity } \\
\text { individual }\end{array}$ & $\begin{array}{c}\text { Activity } \\
\text { gram } \\
\text { tissue }\end{array}$ & $\begin{array}{c}\text { F/L per } \\
\text { individual } \\
\text { per } \\
\text { gram } \\
\text { tissue }\end{array}$ \\
\hline 3rd & $26.749 \mathrm{~d}$ & $955.333 \mathrm{~d}$ & $8.642 \mathrm{~d}$ & $308.643 \mathrm{~d}$ & 3.095 & 3.095 \\
\hline 4th & $40.520 \mathrm{c}$ & $1013.00 \mathrm{c}$ & $14.043 \mathrm{c}$ & $351.067 \mathrm{c}$ & 2.885 & 2.885 \\
\hline 5th & $103.545 \mathrm{~b}$ & $1294.313 \mathrm{~b}$ & $33.770 \mathrm{~b}$ & $422.123 \mathrm{~b}$ & 3.066 & 3.067 \\
\hline 6th & $459.861 \mathrm{a}$ & $1483.423 \mathrm{a}$ & $145.255 \mathrm{a}$ & $468.565 \mathrm{a}$ & 3.166 & 3.165 \\
\hline mean & $157.669 \mathrm{a}$ & $1191.102 \mathrm{a}$ & $50.428 \mathrm{~b}$ & $387.600 \mathrm{~b}$ & 3.053 & 3.053 \\
\hline L.S.D & 4.880 & 5.954 & 4.707 & 4.981 & - & - \\
\hline
\end{tabular}

*/Activity is expressed as enzyme unit $\times 10^{3} /$ individual.

**/ Activity is expressed as enzyme unit $\times 10^{3} /$ g.b.wt.

The results are accordance with those published by Badr (2016). who mentioned that Ceratitis capitata flies of field strains had much higher levels of hydrolases enzymes than the laboratory strain.

\section{REFERENCES}

Ahmed, S. and A. J. Forgash (1976). Non-oxidative enzyme in metabolism of insecticides. Drug. Metabol. Rev., 5: 141-145.

Badr, Faten A. A.(2016). Monitoring resistance in different field strains of the Mediterranean Fruit fly Ceratitis capitata (Wied.) to toxicity of the organophosphorus insecticide in relation to some enzymes activity. Egypt. L. Plant Pro. Res. 4 (39):39-57.

Dixon, M. and E. G. Webb (1964). Enzymes. $2^{\text {nd }}$ Ed. AcademicPress, New York. 
Ellman, G. L.; K. D. Countney; V. Andres and R. m. Featherstone (1961): A new and rapid colorimetric determination of acetylcholinesterase activity. Biochem. Pharmac., 7: 88-95.

Hammad, M. A. (1977). Toxicological studies on bollworm, Heliothis zea. M.Sc. Thesis, Fac. of Agric., Al-Azhar Univ., Cairo.

Hassan, Afaf, I. and Aziza M. Mostafa. (2000). Synergism the toxic action of some organophosphorus insecticides against the Mediterreanean fruit fly, Ceratitis capitata (Wied.) larvae. Egypt. J. Appl. Sci., 15 (11): 334-345.

Hung, H. and J. A. Ottea (2004): Development of pyrethroid substrates for esterase associated with pyrethroid resistance in the tobacco budworm, Heliothis virescens (F.). J. Agric. Food Chem., 52: 6539-6545.

Khidr, A.A. (1982): Toxicological studies on the American bollworm, Heliothis armigera. Ph.D.thesis, Fac.of Agric. Zagazig Univ.

Meyers, D.R. (1959). Carboxyl ester cleavage(syrvey). In the enzymes(Eds. Boyer D.D., H.A. Lardy, and K. Myrback) $2^{\text {nd }}$ Ed, 4: 475-483.

Joußen, N. and D.G. Heckel (2016): Resistance Mechanisms of Helicoverpa armigera. Advances in Insect Control and Resistance Management, Springer International Publishing Switzerland, pp 241-261.

Powell, M. E. A. and M. J. H. Smith (1954): The determination of serum acid and alkaline phosphatases activity with 4-amino antipyrine. J. Clin. Patho., 7: 245-248.

Seleman, Laila, E. (2014). Monitoring resistance in different strains of pink bollworm, Pectinophora gossypiella (saund.) to profenofos and its relation to some biochemical aspects., Egypt. Acad. J. Biol. Sci.,7 (1): 141-152.

Siegfried, B. A. and A. J. Zera (1994). Partial purification and characterization of a green bug (homoptera, aphidae) esterase associated with resistance to parathion. Pestic., Biochemistry and Phisiol., 49 : 132-137. 
Sudderuddin, K. I. (1973). An electrophretic study of some hydrolases from an organophosphate-susceptible and organophosphate - resistant strains of the green peach aphid, Myzus persicae. Comp. Biochem. Physiol., 44 B (3):923-927.

Van Aspren, K. (1962). A study of house fly esterases by means of sensitive colourimetric method. J. Insect Physiol., 8:401-416.

Wilson, T. G. and M. Ashok (1998). Insecticide resistance resulting from an absence of target -site gene product. Proc. Natl. Acad. Sci., U. S. A., 95 (24): 14040-14044.

Young, S.J.; R.V. Gunning and G.D. Moores. (2005): The effect of piperonyl butoxideon Pyrethroid-resistance-associated esterases in Helicoverpa armigera (Hubner) (Lepidoptera: Noctuidae).Pest Manag. Sci 61:397-401.

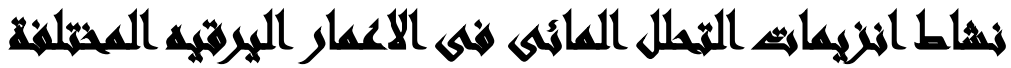

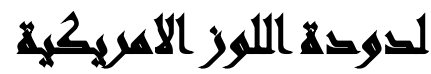

[^]

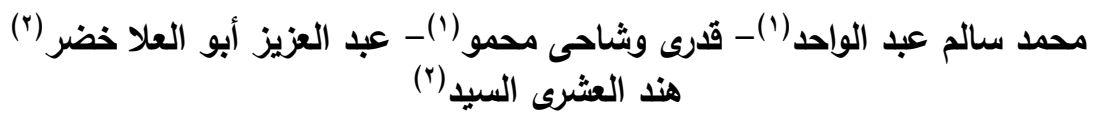

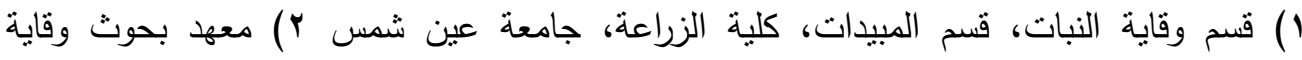

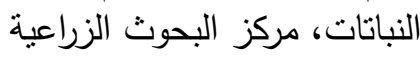

\section{المستخلمع}

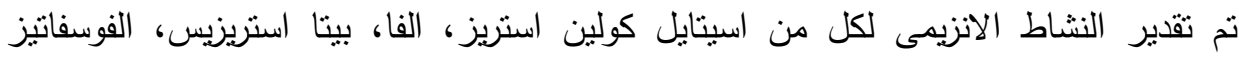

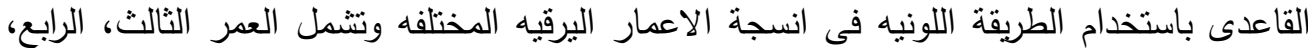

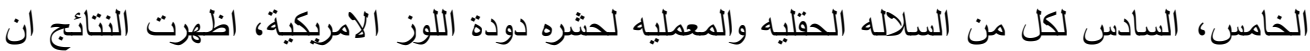

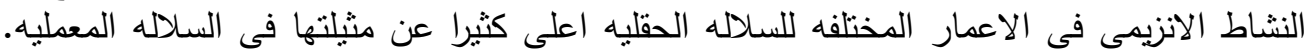

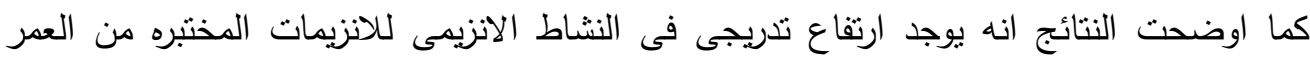

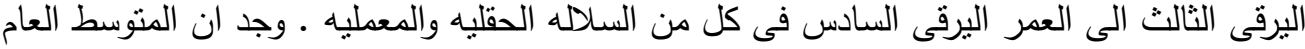
للنشاط الانزيمى للاعمار اليرقيه المختلفه في السلاله الحقليه والمعمليه كما يلى على اليى الترتيب: 


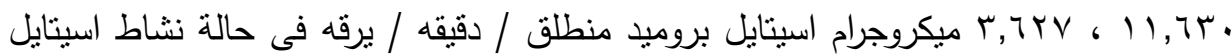

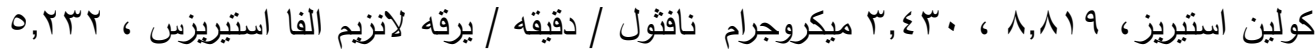

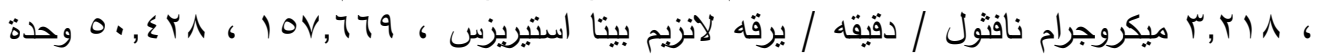

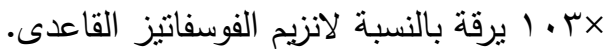

